\title{
Amplified Fragment Length Polymorphism and Parentage Analysis of a Feral Barberry (Berberis thunbergii DC.) Population to Determine the Contribution of an Ornamental Landscape Genotype
}

Jessica D. Lubell' ${ }^{2}$, Mark H. Brand, and Jonathan M. Lehrer ${ }^{1}$ Department of Plant Science, University of Connecticut, 1376 Storrs Road, Unit 4067, Storrs, CT 06269-4067

Kent E. Holsinger

Department of Ecology and Evolutionary Biology, U-3043, University of Connecticut, Storrs, CT 06269-3043

Additional index words. amplified fragment length polymorphism, invasive plant, molecular markers, parentage analysis

\begin{abstract}
We investigated the role of an ornamental, purple-leaved specimen of Japanese barberry in a local invasion using parentage analysis. We focused on a landscape plant of B. thunbergii var. atropurpurea in Willington, CT, that was first established at least 30 years ago. We genotyped every barberry plant found within a 92-m radius of this individual. In contrast to feral populations that are distant from residential or commercial plantings, $\mathbf{1 4 \%}$ of the $\mathbf{4 3}$ feral plants in our sample had purple foliage and $30 \%$ were found growing within $16.5 \mathrm{~m}$ of the focal individual. Parentage analysis identified seven plants (five purple-leaved and two green-leaved) as descendants of the focal individual. Five of these descendants are likely first-generation offspring and two are likely second-generation seedlings. In addition, one plant was identified as a backcross between the focal plant and one of its offspring. Our results show that purple-leaved Japanese barberry used in residential landscapes can contribute to plant invasions, at least under some circumstances.
\end{abstract}

Invasive populations of Japanese barberry (Berberis thunbergii DC.) are currently found in 30 states across the United States (Anonymous, 2007). Barberry plants are established from seed, which is primarily dispersed by birds and small rodents (Decker et al., 1991; Silander and Klepeis, 1999). Feral seedlings may form impenetrable thickets that displace native flora (Clark et al., 1998) and alter soil chemistry, microbial communities, and earthworm populations (Ehrenfeld et al., 2001).

Since its introduction to U.S. cultivation in the late 1800 s, Japanese barberry has become one of the most popular horticultural plants as a result of its hardiness, ease of culture, resistance to deer browsing, and general attractiveness (Steffey, 1985). This plant holds substantial market share in the U.S. commercial horticulture industry, and in Connecticut alone, the barberry crop is worth $\$ 5$ million in

Received for publication 30 Sept. 2008. Accepted for publication 4 Jan. 2009.

${ }^{1}$ Current address: Department of Ornamental Horticulture, Farmingdale State College, Farmingdale, NY 11735.

${ }^{2}$ To whom reprint requests should be addressed; e-mail jessica.lubell@uconn.edu. retail sales (Heffernan, 2005). Current cultivated forms of Japanese barberry (B. thunbergii var. atropurpurea) have purple foliage, whereas feral barberry have green leaves and plants resemble the species, $B$. thunbergii, which is rarely found in cultivation today.

Japanese barberry bans in Massachusetts (Anonymous, 2005) and New Hampshire (Anonymous, 2004) and those being considered by other states across the United States do not differentiate between the species and its purple-leaved forms (Harrington et al., 2003). Because it is uncertain whether the offspring from cultivated purple-leaved genotypes establish in natural habitats, legislation banning all Japanese barberry is controversial.

The objective of this study was to determine the degree to which a purple-leaved barberry in a residential landscape can contribute offspring to a surrounding invasive population or initiate a new invasion in adjacent unmanaged areas. For this work, we identified a location where a purpleleaved barberry used as a landscape plant was surrounded by feral barberries of various ages and sizes invading unmanaged land. Amplified fragment length polymorphism
(AFLP) parentage analysis, in combination with morphological and spatial information, was used to determine the extent to which the cultivated landscape plant had contributed to the surrounding feral barberry population.

\section{Materials and Methods}

Plant material. We chose a location in Willington, CT (long. $41^{\circ} 50^{\prime} \mathrm{N}$, lat. $72^{\circ} 16^{\prime}$ $\mathrm{W}$; elevation $580 \mathrm{ft}$ ) with a cultivated specimen of $B$. thunbergii var. atropurpurea (purple foliage) that was established at least 3 decades ago (as confirmed by landowners) and with feral plants of unknown parentage in the surrounding area. All plants (45 in total) within a 92-m radius of the specimen plant [putative originator plant (POP)] were included in the analysis. We recorded the height, width, depth, foliage color, number of shoots, reproductive status, and the distance to POP for every individual in the sample (Table 1; Fig. 1). Shoots were counted at the base of the plant $\approx 12 \mathrm{~cm}$ up from the ground. We used plant height, width, and depth to calculate an index of plant size (plant height $\times$ plant width $\times$ plant depth). Plant age was estimated using plant size, number of shoots, and reproductive status. Plants were considered reproductive if they possessed one or more fruits. Reproductive plants were assigned a value of one and nonreproductive plants were assigned a value of zero. We calculated a weighted age index for each plant using the formula (reproductive status $\times 0.2$ ) + (plant size $\times 0.4)+$ (number of shoots $\times$ 0.4 ). The onset of fruiting is variable for $B$. thunbergii plants depending on their location, so less weight was given to this factor in the age formula. Based on the age index, plants were divided into four age classes (seedling, young plant, adult plant, and old adult plant). The age index cutoff values for the age classes were 1 to 2 for seedling, 3 to 8 for young plant, 9 to 15 for adult plant, and 16 or greater for old adult plant.

DNA extraction and amplified fragment length polymorphism analysis. In 2006, leaves were collected for DNA extraction and AFLP analysis. In total, 46 plants were sampled, including POP. Leaves were temporarily held on ice before being stored at $-80{ }^{\circ} \mathrm{C}$ until DNA extraction. DNA extraction was conducted according to the protocol described in Lubell et al. (2008a), which was adapted from Perry et al. (1998) and Cheng et al. (1997). AFLP analysis using Eco-RI and Mse-I enzymes was conducted according to the protocol outlined in Vos et al. (1995) with the following modifications. We used 350 to 500 ng of DNA in each AFLP reaction. For selective polymerase chain reaction (PCR) amplification, six primer pairs were used and each primer had three selective nucleotides. The primer pairs were $E+$ $\mathrm{AGG} / M+\mathrm{CAA}, E+\mathrm{AGG} / M+\mathrm{CTG}, E+$ $\mathrm{ACC} / M+\mathrm{CTC}, E+\mathrm{ACC} / M+\mathrm{CTT}, E+$ $\mathrm{ACG} / M+\mathrm{CAC}$, and $E+\mathrm{ACA} / M+\mathrm{CTG}$. Fluorescently labeled Eco RI primers were purchased from Applied Biosystems (Foster City, CA) or Fisher Scientific (Hampton, NH). 
Table 1. Descriptions for the 46 sampled Berberis thunbergii plants at the Willington, CT, study site.

\begin{tabular}{|c|c|c|c|c|c|c|c|c|}
\hline $\begin{array}{l}\text { Plant } \\
\text { no. }\end{array}$ & $\begin{array}{l}\text { Distance }^{y} \\
(\mathrm{~m})\end{array}$ & $\begin{array}{l}\text { Foliage } \\
\text { Color }^{\mathrm{x}}\end{array}$ & $\begin{array}{l}\text { Reproductive } \\
\text { status }^{\mathrm{w}}\end{array}$ & $\begin{array}{c}\text { No. } \\
\text { shoots }\end{array}$ & $\begin{array}{c}\text { Plant } \\
\text { size }\left(\mathrm{m}^{3}\right)\end{array}$ & $\begin{array}{l}\text { Age } \\
\text { index }\end{array}$ & $\begin{array}{l}\text { Age } \\
\text { class }^{u}\end{array}$ & $\begin{array}{c}\text { Designation for } \\
\text { parentage analysis } \\
\text { (narrow/expanded) }\end{array}$ \\
\hline$\overline{\mathrm{POP}^{\mathrm{z}}}$ & 0 & $\mathrm{P}$ & Yes & 58 & 14.00 & 29 & $\mathrm{O}$ & par/par \\
\hline 2 & 2.1 & $\mathrm{P}$ & Yes & 18 & $\mathrm{~N} / \mathrm{C}^{\mathrm{s}}$ & $\mathrm{N} / \mathrm{C}$ & A (est.) & par/par \\
\hline 3 & 2.1 & G & Yes & 46 & 12.15 & 23 & $\mathrm{O}$ & par/par \\
\hline 4 & 25.9 & G & Yes & 30 & 3.74 & 14 & $\mathrm{~A}$ & par/par \\
\hline 5 & 64.0 & G & Yes & 64 & 11.90 & 31 & $\mathrm{O}$ & par/par \\
\hline 6 & 33.5 & G & Yes & 64 & 8.21 & 29 & $\mathrm{O}$ & par/par \\
\hline 7 & 25.9 & G & Yes & 28 & 6.05 & 14 & $\mathrm{~A}$ & par/par \\
\hline 8 & 14.6 & $\mathrm{P}$ & Yes & 19 & 1.39 & 8 & $\mathrm{Y}$ & off/par \\
\hline 9 & 16.5 & $\mathrm{P}$ & Yes & 8 & 0.43 & 4 & $\mathrm{Y}$ & par/off \\
\hline 10 & 14.9 & G & No & 4 & 0.08 & 2 & $\mathrm{~S}$ & off/off \\
\hline 11 & 10.4 & G & No & 3 & 0.07 & 1 & $\mathrm{~S}$ & off/off \\
\hline 12 & 9.4 & G & No & 1 & 0.01 & 1 & $\mathrm{~S}$ & off/off \\
\hline 13 & 16.5 & G & No & 4 & 0.42 & 2 & $\mathrm{~S}$ & off/off \\
\hline 14 & 14.9 & G & No & 1 & $\mathrm{~N} / \mathrm{C}$ & $\mathrm{N} / \mathrm{C}$ & S (est.) & off/off \\
\hline 15 & 90.8 & $\mathrm{P}$ & No & 2 & 0.01 & 1 & $\mathrm{~S}$ & off/off \\
\hline 16 & 73.2 & $\mathrm{RG}$ & Yes & 22 & 0.90 & 9 & A & par/par \\
\hline 17 & 50.3 & RG & Yes & 9 & 0.14 & 4 & $\mathrm{Y}$ & off/par \\
\hline 18 & 55.5 & G & No & 6 & 0.12 & 3 & $\mathrm{Y}$ & off/off \\
\hline 19 & 21.3 & G & No & 1 & 0.03 & 1 & $\mathrm{~S}$ & off/off \\
\hline 20 & 65.8 & $\mathrm{P}$ & No & 3 & 0.02 & 1 & $\mathrm{~S}$ & off/off \\
\hline 21 & 85.3 & G & No & 1 & $\mathrm{~N} / \mathrm{C}$ & $\mathrm{N} / \mathrm{C}$ & S (est.) & off/off \\
\hline 22 & 40.5 & G & Yes & 4 & 0.85 & 2 & $\mathrm{~S}$ & off/par \\
\hline 23 & 85.3 & G & No & 1 & $\mathrm{~N} / \mathrm{C}$ & $\mathrm{N} / \mathrm{C}$ & S (est.) & off/off \\
\hline 24 & 89.6 & G & Yes & 1 & 0.12 & 1 & $\mathrm{~S}$ & off/par \\
\hline 25 & 85.3 & $\mathrm{P}$ & No & 1 & $\mathrm{~N} / \mathrm{C}$ & $\mathrm{N} / \mathrm{C}$ & S (est.) & off/off \\
\hline 26 & 41.5 & G & Yes & 14 & 1.90 & 7 & $\mathrm{Y}$ & off/par \\
\hline 27 & 62.2 & G & Yes & 8 & 0.73 & 4 & $\mathrm{Y}$ & off/par \\
\hline 28 & 90.2 & G & Yes & 15 & 1.69 & 7 & $\mathrm{Y}$ & off/par \\
\hline 29 & 90.8 & G & Yes & 5 & 0.29 & 2 & $\mathrm{~S}$ & off/par \\
\hline 30 & 91.4 & G & Yes & 1 & 0.14 & 1 & $\mathrm{~S}$ & off/par \\
\hline 31 & 86.9 & G & Yes & 11 & 1.79 & 5 & $\mathrm{Y}$ & off/par \\
\hline 32 & 87.5 & G & Yes & 8 & 0.25 & 3 & $\mathrm{Y}$ & off/par \\
\hline 33 & 89.3 & G & No & 3 & 0.04 & 1 & $\mathrm{~S}$ & off/off \\
\hline 34 & 69.5 & G & Yes & 10 & 1.65 & 5 & $\mathrm{Y}$ & off/par \\
\hline 35 & 63.7 & G & Yes & 1 & $\mathrm{~N} / \mathrm{C}$ & $\mathrm{N} / \mathrm{C}$ & S (est.) & off/par \\
\hline 36 & 90.2 & G & Yes & 3 & 0.21 & 1 & $\mathrm{~S}$ & off/par \\
\hline 37 & 64.0 & G & No & 4 & 0.11 & 2 & $\mathrm{~S}$ & off/off \\
\hline 38 & 18.9 & G & No & 1 & 0.01 & 1 & $\mathrm{~S}$ & off/off \\
\hline 39 & 56.7 & G & No & 2 & 0.03 & 1 & $\mathrm{~S}$ & off/off \\
\hline 40 & 56.1 & G & No & 4 & 0.03 & 2 & $\mathrm{~S}$ & off/off \\
\hline 41 & 56.4 & $\mathrm{G}$ & No & 3 & 0.04 & 1 & $\mathrm{~S}$ & off/off \\
\hline 42 & 7.6 & G & No & 3 & 0.02 & 1 & $\mathrm{~S}$ & off/off \\
\hline 43 & 9.1 & G & No & 3 & 0.01 & 1 & $\mathrm{~S}$ & off/off \\
\hline 44 & 10.1 & G & No & 2 & 0.01 & 1 & $\mathrm{~S}$ & off/off \\
\hline 45 & 10.4 & G & No & 3 & 0.01 & 1 & $\mathrm{~S}$ & off/off \\
\hline 46 & 19.8 & G & No & 13 & 0.95 & 6 & $\mathrm{Y}$ & off/off \\
\hline
\end{tabular}

${ }^{2} \mathrm{POP}=$ purple-leaved originator $B$. thunbergii var. atropurpurea plant. 'Distance to POP.

${ }^{\mathrm{x}} \mathrm{G}=$ green; $\mathrm{P}=$ purple; $\mathrm{RG}=$ B. thunbergii 'Rose Glow' (purple variegated foliage).

${ }^{\mathrm{w}}$ Yes $=$ assigned a value of $1 ; \mathrm{No}=$ assigned a value of 0 .

${ }^{v}$ Age index $=($ reproductive $\times 0.2)+($ no. shoots $\times 0.4)+($ plant size $\times 0.4)$.

"S = seedling, 1-2 index; $\mathrm{Y}=$ young plant, 3-8 index; $\mathrm{A}=$ adult plant, $9-15$ index; $\mathrm{O}=$ old adult plant, $16 \leq$ index

toff $=$ offspring; par $=$ parent

${ }^{\mathrm{s}} \mathrm{N} / \mathrm{C}=$ data not collected.

The amplification parameters for selective PCR were as follows: a 20 -s denaturation step at $94{ }^{\circ} \mathrm{C}$, a 30 -s annealing step that started at $66{ }^{\circ} \mathrm{C}$ and was subsequently reduced by $1{ }^{\circ} \mathrm{C}$ per cycle for 10 cycles and was continued at $56^{\circ} \mathrm{C}$ for 20 cycles, and a 2min extension step at $72{ }^{\circ} \mathrm{C}$. Completed reactions were analyzed on an ABI 3100 Prism ${ }^{\circledR}$ Genetic Analyzer (Applied Biosystems). Samples were prepared by mixing 0.4 $\mu \mathrm{L}$ Genescan ${ }^{\circledR}$ 400HD [ROX] size standard (Applied Biosystems), 9.6 $\mu \mathrm{L}$ deionized formamide, and $1 \mu \mathrm{L}$ each of three selective products amplified using Eco RI primers with different fluorescent color labels.
Parentage analysis. AFLP markers were scored initially using Genotyper ${ }^{\circledR} 3.6$ software (Applied Biosystems). Each marker identified by the software was visually confirmed for each sample. We conducted a parentage analysis using 70 polymorphic AFLP markers and FaMoZ software. Using allele frequencies, FaMoZ calculates " $\log$ of the odds ratio" scores for any parent pair relationships and statistically determines parentage assignments (Gerber et al., 2003). Because AFLP markers are dominant, we were not able to identify which parent was maternal and which was paternal. The parent-offspring relationships were determined at inbreeding coefficients of 0.05 and 0.3 . These coefficients were chosen because they define a conservative range likely to cover the true inbreeding coefficient for a woody, outcrossing, insect-pollinated species (Gerber et al., 2003; Sezen et al., 2005) such as $B$. thunbergii. Parentage was assigned only when the offspring were assigned to the same parent or parent pairs at both inbreeding coefficients. FaMoZ was run twice using different sets of potential parents, a "narrow" set and an "expanded" set. The narrow set consisted of the eight plants with the highest age indices and was used to identify the parentage of larger young plants that may have come from POP (Table 1). The expanded set included all plants that were reproductive and was used to gain a complete understanding of the parentage relationships.

\section{Results and Discussion}

Of the 70 AFLP markers used for this parentage analysis, 43 had allele frequencies in the range of 0.1 to 0.4 . According to Gerber et al. (2000), AFLP markers with allele frequencies in this range are more informative for parentage analysis than those with frequencies outside of this range. The number of markers with frequencies of 0.1 to 0.4 used here was similar to the number used in other studies of woody plant species. For example, Gerber et al. (2000) successfully used 45 AFLP markers with frequencies from 0.1 to 0.4 for parentage analysis with oak trees. Two of the three authors on that study were involved in producing the FaMoZ software (Gerber et al., 2003).

In addition to the putative originator B. thunbergii var. atropurpurea plant (POP), we found two additional landscape plants (both B. thunbergii 'Rose Glow'; Plants 16 and 17; Fig. 1) and 43 feral plants. The additional landscape plants were established within the past 5 to 7 years by the homeowner. Of the feral plants, $9 \%$ were old adult, $9 \%$ were adult, $20 \%$ were young, and $62 \%$ were seedlings (Table 1 ). Half of the plants sampled were reproductive, but the quantity of fruit produced varied per plant.

Thirty percent of feral plants were found growing within $16.5 \mathrm{~m}$ of POP in an area on the property of Homeowner 1 . The property was occupied by scattered eastern white pine (Pinus strobus L.) and stone walls (Fig. 1). In New England, feral barberries are commonly found growing along stone walls. The crevices between the rocks at the base of walls may be a preferred microenvironment that offers light shade, adequate moisture, and protection for seed germination and establishment. Most other feral barberries were found growing in partially shaded to shaded locations, including the shrubby hedgerow on the east side of Connecticut state Route 320 and the woods at the northeast corner of the study site (Fig. 1). Fourteen percent of feral plants had purple foliage. Although this figure falls within the known range (11\% to $76 \%)$ for purple seedling production from landscape $B$. thunbergii var. atropurpurea plants (Lehrer et al., 2006), 


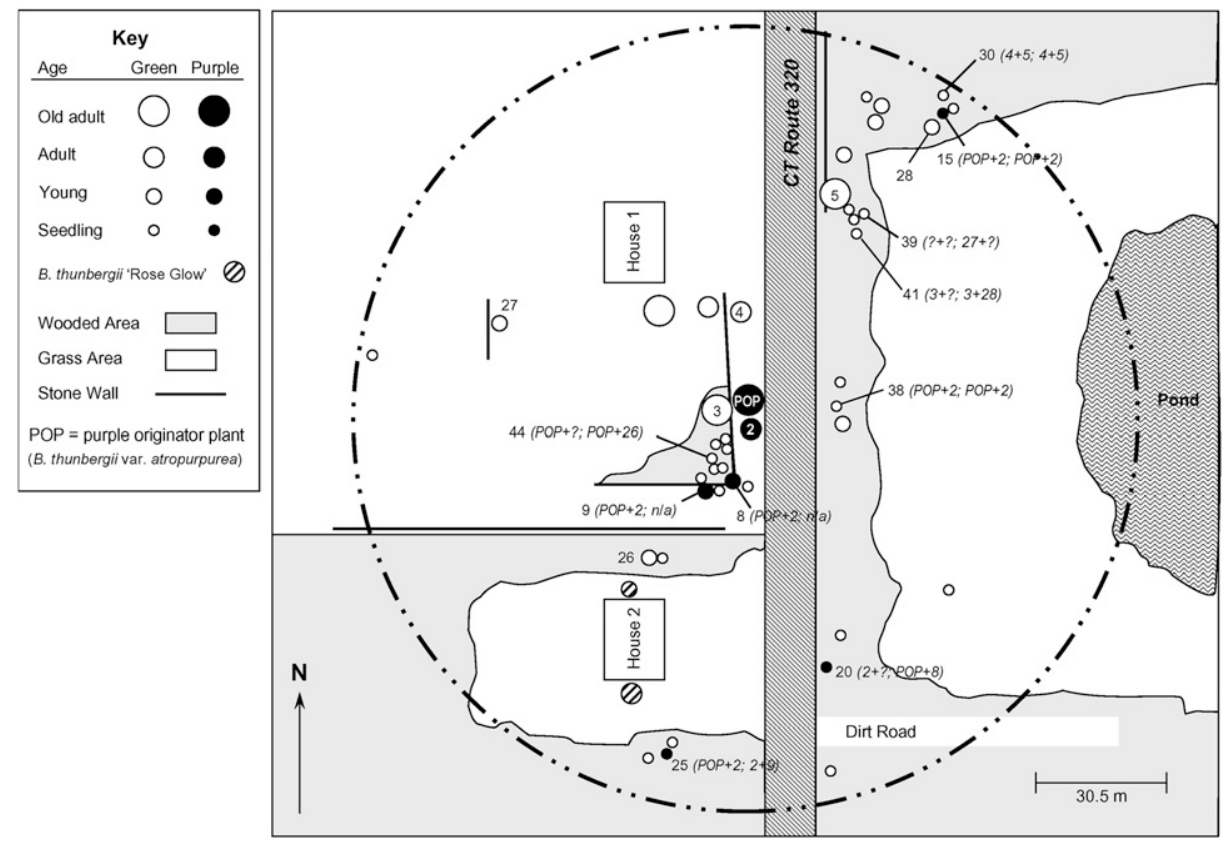

Fig. 1. Map of the Willington, CT, study site showing the relative distances between feral plants and the putative originator Berberis thunbergii var. atropurpurea plant (POP), the age indices, foliage color, and, where applicable, parentage, for sampled plants. Plant numbers, assigned at the start of the study, are shown only for plants that were identified as a parent or an offspring by parentage analysis. Numbers in parentheses represent parentage assignments. The first set indicates the parents from the "narrow" analysis and the second set indicates the parents from the "expanded" analysis.

the number of purple feral plants at the Willington, CT, site was much higher than what was found in several long-established invasive populations in New England that are more distant from residential or commercial plantings (Lubell et al., 2008b).

We were able to assign parentage for 10 feral plants, seven of which were descendents of POP (Fig. 1). For the unassigned individuals, their parents may be located outside the study area or may have been removed or died. It is also possible that parentage might not have been apparent as a result of segregation and loss of heterozygous alleles.

Fifteen percent of the plants in the local population had parentage traced in one or two generations to POP. Three plants, Plants 8 and 9 (purple foliage) and Plant 38 (green foliage), were located within $19 \mathrm{~m}$ of POP and were identified as the offspring of POP and Plant 2 by parentage analysis (Fig. 1). The position of Plant 2, immediately adjacent to POP, and Plant 2's purple phenotype suggests that it is a seedling of POP, although parentage could not be assigned by FaMoZ analysis. Plant 44 was another confirmed offspring of POP found within $11 \mathrm{~m}$ of its parent (Fig. 1). Although long-distance seed dispersal has been reported to be rare for $B$. thunbergii (Silander and Klepeis, 1999), Plant 15 (purple foliage) was $90.8 \mathrm{~m}$ away from POP and was identified as an offspring of POP and Plant 2 (Fig. 1). In their study of barberry seed dispersal, Silander and Klepeis (1999) report that the majority of seedlings $(92 \%)$ found were underneath or within $1 \mathrm{~m}$ of the canopy of a barberry shrub. However, they also discovered several seedlings at $50+\mathrm{m}$ and one at $80+\mathrm{m}$ from the nearest possible source plant.

Two second-generation offspring of POP (20 and 25) were identified at more than $85 \mathrm{~m}$ away from POP (Fig. 1). One of these plants (20) was produced from a backcross between POP and one of its offspring, Plant 8 . The second plant (25) arose from a cross between Plant 2 and Plant 9, another offspring of POP. We believe that POP gave rise to Plants 8, 9, and 2 as first-generation progeny. This conclusion is based on their purple foliage color, position in the landscape relative to POP, and their intermediate size and age. Parentage could be determined for three other feral plants, Plants 30,39 , and 41 , which were located in the northeast corner of the study site (Fig. 1). The parents for Plant 30 were 4 and 5 , and for Plant 41, they were 3 and 28. Only Plant 27 could be assigned as a parent of Plant 39 .

POP was not found to be a parent of the two cultivated $B$. thunbergii 'Rose Glow' plants located within the study site, although 'Rose Glow' is reported to be a selection of B. thunbergii var. atropurpurea (Dirr, 1998). Because B. thunbergii var. atrourpurea is a botanical variety that has been propagated sexually since its discovery in 1913 (Dirr, 1998), considerable genotypic variation exists within the var. atropurpurea population. In previous work (Lubell et al., 2008a), $B$. thunbergii 'Rose Glow' was found to be closely related to some var. atropurpurea genotypes and more distantly related to others, including POP. 'Rose Glow' may have arisen from a var. atropurpurea plant that was sufficiently distinct from POP, so the failure of FaMoZ to assign POP as a parent of 'Rose Glow' is understandable.

The two cultivated $B$. thunbergii 'Rose Glow' plants could not be identified as contributors to the feral population. Although these plants were reproductive, they may have been too young or not enough time had passed in their current location for them to produce viable offspring. It is also possible that seedlings from $B$. thunbergii 'Rose Glow' do not establish as well as seedlings from other barberry genotypes.

This work has clearly demonstrated that a purple-leaved Japanese barberry in a residential landscape can contribute seedlings to an invasive population when the landscape plant is grown within a few hundred meters of a suitable habitat. Although genetic analysis of five invasive barberry populations in southern New England found that $B$. thunbergii var. atropurpurea had limited influence on extant populations of barberry (Lubell et al., 2008 b), four of these populations were not in proximity to any $B$. thunbergii var. atropurpurea landscape plantings. This work provides insight into how a cultivated plant in a residential landscape can impact an invasion and should help invasive plant regulators determine appropriate legislation regarding bans of Japanese barberry.

\section{Literature Cited}

Anonymous. 2004. Adopted rule. Chapter Agr 3800 Invasive species. State of New Hampshire. Nov. 2007. <http://www.nh.gov/agric/divisions/ plant_industry/documents/Rules_8.pdf $>$.

Anonymous. 2005. Massachusetts prohibited plant list. State of Massachusetts. Nov. 2006. <http:// mass.gov/agr/farmproducts/Prohibited_Plant_ Index $2 . h t m>$.

Anonymous. 2007. The PLANTS database. Version 3.5. National Plant Data Center, Baton Rouge, LA. May 2007. <http://plants.usda.gov>.

Cheng, F.S., S.K. Brown, and N.F. Nelson. 1997. A DNA extraction protocol from various tissues in woody species. HortScience 32:921-922.

Clark, F.H., C. Mattrick, and S. Shonbrun. 1998. Rogues gallery: New England's notable invasives. Conservation Notes of the New England Wildflower Society 2:22. 
Decker, S.R., P.J. Penkins, and W.M. Mautz. 1991. Nutritional evaluation of winter foods of wild turkeys. Can. J. Zool. 69:2128-2132.

Dirr, M.A. 1998. Manual of woody landscape plants. 5th Ed. Stipes Publishing, Champaign, IL.

Ehrenfeld, J.G., P. Kourtev, and W. Huang. 2001. Changes in soil functions following invasions of exotic understory plants in deciduous forests. Ecol. Appl. 11:1287-1300.

Gerber, S., P. Chabrier, and A. Kremer. 2003. FaMoZ: A software for parentage analysis using dominant, codominant and uniparentally inherited markers. Mol. Ecol. Notes 3:479481.

Gerber, S., S. Mariette, R. Streiff, C. Bodenes, and A. Kremer. 2000. Comparison of microsatellites and amplified fragment length polymorphism markers for parentage analysis. Mol. Ecol. 9:1037-1048.
Harrington, R.A., R. Kujawski, and H.D.P. Ryan. 2003. Invasive plants and the green industry. J. Arboriculture 29:42-48.

Heffernan, B. 2005. 15 invasive plants of value to the green industry not yet banned in Connecticut. Connecticut Green Industries, Botsford, CT.

Lehrer, J.M., M.H. Brand, and J.D. Lubell. 2006. Seedling populations produced by colored-leaf genotypes of Japanese barberry (Berberis thunbergii DC.) contain seedlings with green leaf phenotype. J. Environmental Hort. 24:133136.

Lubell, J.D., M.H. Brand, and J.M. Lehrer. 2008a. AFLP identification of Berberis thunbergii cultivars, inter-specific hybrids and their parental species. J. Hort. Sci. Biotechnol. 24:133-136.

Lubell, J.D., M.H. Brand, J.M. Lehrer, and K.E. Holsinger. 2008b. Detecting the influence of ornamental Berberis thunbergii var. atropurpurea in invasive populations of Berberis thunbergii (Berberidaceae) using AFLP. Amer. J. Bot. 95:700-705.

Perry, M.D., M.R. Davey, J.B. Power, K.C. Lowe, H.F.J. Bligh, P.S. Roach, and C. Jones. 1998. DNA isolation and AFLP genetic fingerprinting of Theobroma cacao (L.). Plant Mol. Biol. Rpt. 16:49-59.

Sezen, U.U., R.L. Chazdon, and K.E. Holsinger. 2005. Genetic consequences of tropical secondgrowth forest regeneration. Science 307:891.

Silander, J.A. and D.M. Klepeis. 1999. The invasion ecology of Japanese barberry (Berberis thunbergii) in the New England landscape. Biol. Invasions 1:189-201.

Steffey, J. 1985. Strange relatives: The barberry family. American Horticulturalist 64:4-9.

Vos, P.R., R. Hogers, M. Bleeker, M. Reijans, T. Van De Lee, M. Hornes, A. Fijters, J. Pot, M. Kuiper, and M. Zabeau. 1995. AFLP: A new technique for DNA fingerprinting. Nucleic Acids Res. 23:4407-4414. 